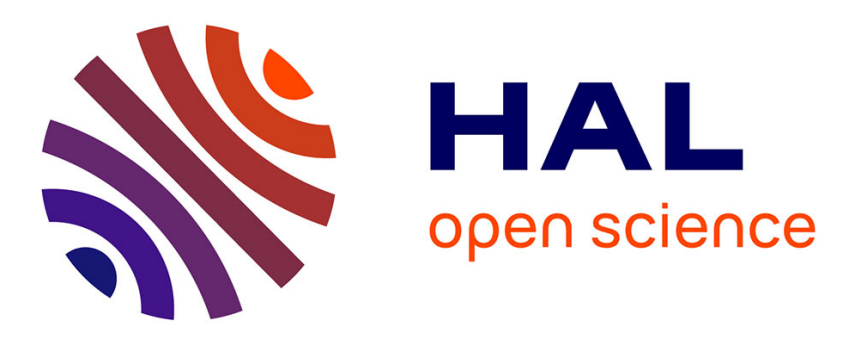

\title{
Advanced Numerical Strategy for the Prediction of Unsteady Flow Aerodynamics around Complex Geometries
}

\author{
Pierre-Elie Weiss, Sébastien Deck
}

\section{- To cite this version:}

Pierre-Elie Weiss, Sébastien Deck. Advanced Numerical Strategy for the Prediction of Unsteady Flow Aerodynamics around Complex Geometries. 7th symposium on Hybrid RANS-LES methods, Sep 2018, BERLIN, Germany. hal-01994063

\section{HAL Id: hal-01994063 https://hal.science/hal-01994063}

Submitted on 15 Feb 2019

HAL is a multi-disciplinary open access archive for the deposit and dissemination of scientific research documents, whether they are published or not. The documents may come from teaching and research institutions in France or abroad, or from public or private research centers.
L'archive ouverte pluridisciplinaire HAL, est destinée au dépôt et à la diffusion de documents scientifiques de niveau recherche, publiés ou non, émanant des établissements d'enseignement et de recherche français ou étrangers, des laboratoires publics ou privés. 
Session:

\title{
Advanced Numerical Strategy for the Prediction of Unsteady Flow Aerodynamics around Complex Geometries
}

\author{
Pierre- Élie Weiss and Sébastien Deck \\ DAAA, ONERA, Université Paris Saclay, F-92190 Meudon - \\ France
}

One of the future challenges in Computational Fluid Dynamics deals with the ability to simulate quantitatively the physical phenomena driving the multi-scale physics of turbulent flows around complex geometries. Considering this frame, the present work focuses on an advanced numerical methodology named ZIBC standing for Zonal Immersed Boundary Conditions [1,2,3] enabling to account for realistic configurations $[4,5,6,7]$ at high Reynolds numbers. The numerical strategy allowing the coupling between a modelling method (e.g. RANS, URANS, ZDES, LES or DNS) and IBC (Immersed Boundary Conditions) is detailed. In this paper, the modelling method retained is the Zonal Detached Eddy Simulation (ZDES) which has reached a high level of maturity on turbulent separated flows $[8,9,10]$. Then, the numerical strategy can be applied to complex configurations dealing with internal or external Aerodynamics such as a full space launcher configuration. As an example, Fig. 1(a) illustrates the feasibility to simulate the interactions between the technological details, treated with IBC, and the simplified afterbody, modelled with a body-fitted (BF) approach consisting in classical adiabatic no-slip boundary conditions, in the turbulent flow field surrounding the main stage of the space launcher afterbody. In particular, the ZIBC simulation allows to return the salient unsteady features of the flow field such as the wall pressure fluctuations (see Fig. 1(b)).

\section{References}

[1] Mochel, L., Weiss, P.-E., and Deck, S., “Zonal Immersed Boundary Conditions: Application to a high Reynolds number afterbody flow," AIAA Journal, Vol. 52, No. 12, pp. 2782-2794, 2014.

[2] Weiss, P.-E. and Deck, S. On the coupling of a zonal body-fitted/immersed boundary method with ZDES: application to the interactions on a realistic space launcher afterbody flow, Comput. \& Fluids, https://doi .org /10 .1016 /j .compfluid .2017.06 .015, in press. 2017. 
Session:
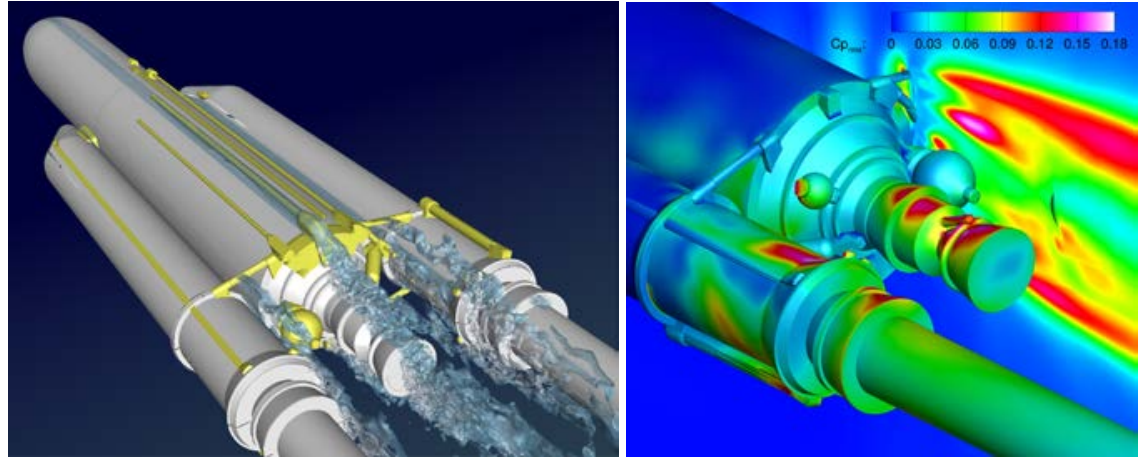

Fig. 1 (a) Thick slices of the instantaneous streamwise velocity field of the ZDES simulation around a full space launcher modelled with ZIBC : grey parts ('clean' configuration) are modelled with a body-fitted (BF) approach, yellow parts (technological details) are taken into account using an immersed boundary (IB) method. (b) Contours of the fluctuating pressure coefficient $C p_{r m s}$ at the wall and in the flow field.

[3] Deck, S., Weiss P.-E. and Renard, N., A rapid and low noise switch from RANS to WMLES on curvilinear grids with compressible flow solvers, Journal of Computational Physics, Vol. 363, pp. 231-255, 2018.

[4] Hannemann, K., Pallegoix, J.-F., Lambaré ', H., Maseland, J. J., Frey, M., Deck, S., Schrijer, F. F. J., and Schwane, R., "Launch Vehicle Base Buffeting: Recent Experimental and Numerical Investigations," Proceedings of the 7th European Symposium on Aerothermodynamics for Space Vehicles, ESA Communications, ESTEC, Noordwijk, The Netherlands, May 2011.

[5] Schwane, R., "Numerical Prediction and Experimental Validation of Unsteady Loads on ARIANE 5 and VEGA," Journal of Spacecraft and Rockets, Vol. 52, pp. 54-62, 2015.

[6] Pain, R., Weiss, P. E., and Deck, S., "Zonal Detached Eddy Simulation of the flow around a simplified launcher afterbody,"

AIAA Journal, Vol. 52, pp. 1967-1979, 2014.

[7] Weiss, P.-E. and Deck, S., "ZDES of the flow dynamics on an Ariane 5-type afterbody with and without struts," $6^{\text {th }}$ European Conference for Aerospace Sciences, Flight Physics, Launcher Aerodynamics, 2015.

[8] Deck, S. and Thorigny, P., "Unsteadiness of an axisymmetric separatingreattaching flow,” Physics of Fluids, Vol. 19, No. 065103, 2007.

[9] Weiss, P.-E., Deck, S., Robinet, J. C., and Sagaut, P., "On the dynamics of axisymmetric turbulent separating/reattaching flows," Physics of Fluids, Vol. 21, No. 075103, 2009.

[10] Weiss, P.-E. and Deck, S., "Control of the antisymmetric mode $(m=1)$ for high Reynolds axisymmetric turbulent separating/reattaching flows", Physics of Fluids, Vol. 23, No. 095102, 2011. 